\title{
Leukotriene $A_{4}$ hydrolase: a critical role of glutamic acid-296 for the binding of bestatin
}

\author{
Martina ANDBERG, Anders WETTERHOLM, Juan F. MEDINA* and Jesper Z. HAEGGSTRÖM ${ }^{1}$ \\ Department of Medical Biochemistry and Biophysics, Division of Chemistry II, Karolinska Institutet, S-171 77 Stockholm, Sweden
}

Leukotriene $\mathrm{A}_{4}$ hydrolase is a bifunctional $\mathrm{Zn}^{2+}$-containing enzyme catalysing the formation of the potent chemotaxin leukotriene $\mathrm{B}_{4}$. From an analysis of three mutants of Glu-296 we have found that this catalytic residue is critical for the binding of bestatin, a classical aminopeptidase inhibitor. For bestatin, but not for three other tight-binding inhibitors, the $\mathrm{IC}_{50}$ values for inhibition of the epoxide hydrolase activity decreased in the mutants to $0.7-0.003 \%$ of the control. Hence Glu-296 is an important structural determinant for binding of bestatin to leukotriene $\mathrm{A}_{4}$ hydrolase; this conclusion might also apply to other members of the M1 family of metallopeptidases.

Key words: aminopeptidase, inflammation, leukotriene $\mathrm{B}_{4}$, mutagenesis, zinc.

\section{INTRODUCTION}

Leukotriene $\mathrm{A}_{4}\left(\mathrm{LTA}_{4}\right)$ hydrolase (EC 3.3.2.6) catalyses the final step in the biosynthesis of the potent chemotaxin leukotriene $\mathrm{B}_{4}$ $\left(\mathrm{LTB}_{4}\right)$. The substrate of this reaction, i.e. the labile epoxide intermediate $\mathrm{LTA}_{4}$, is formed from arachidonic acid via the enzyme 5-lipoxygenase [1]. $\mathrm{LTA}_{4}$ hydrolase is a soluble (molecular mass approx. $69 \mathrm{kDa}$ ) epoxide hydrolase, ubiquitous in mammalian tissues. Enzyme catalysis is typically accompanied by the inactivation and covalent coupling of $\mathrm{LTA}_{4}$ to the protein, apparently at Tyr-378 [2,3].

LTA $_{4}$ hydrolase contains a zinc-binding motif structurally similar to those present in certain zinc proteases, e.g. aminopeptidase $\mathrm{N}$ and thermolysin (Figure 1). Consequently, LTA hydrolase contains one catalytic $\mathrm{Zn}^{2+}$ ion complexed to His-295, His-299 and Glu-318 [4-6]. In addition, the enzyme possesses a peptide-cleaving activity with specificity for arginyl dipeptides and tripeptides [6-8]. However, the physiological substrate for the peptidase is not yet known. On the basis of the zinc signature (Figure 1), the peptidase activity and the overall structural similarity, $\mathrm{LTA}_{4}$ hydrolase has been classified as a member of the M1 family of metallopeptidases [9].

Some of the zinc proteases and aminopeptidases also share a conserved Glu residue, in juxtaposition to the first $\mathrm{Zn}^{2+}$-binding

\section{$\mathrm{L}_{1} \quad \mathrm{~L}_{2} \quad \mathrm{~L}_{3}$}

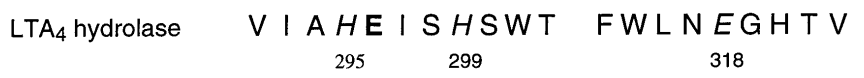

Aminopeptidase N V I AHELAHQWT LWLNEGFAS $388 \quad 392 \quad 411$

Aminopeptidase B V I I HE I SHSWF FWLNEGFTM $323 \quad 327 \quad 346$

Figure 1 Sequence comparison between the $\mathrm{Zn}^{2+}$-binding motifs of $\mathrm{LTA}_{4}$ hydrolase, aminopeptidase $\mathbf{N}$ and aminopeptidase $\mathrm{B}$

All three enzymes are members of the M1 family of metallopeptidases. ligand $\left(\mathrm{L}_{1}\right.$ in Figure 1) [10]. In a previous study we showed that mutation of Glu-296, the corresponding residue in LTA $_{4}$ hydrolase, abrogated the peptidase activity with only minor effects on the epoxide hydrolase activity [11]. Hence Glu-296 is critical for the peptidase activity, in which it probably acts as a general base. Because both enzyme activities are closely related, as judged by substrate competition, susceptibility to competitive inhibitors, and requirement for $\mathrm{Zn}^{2+}$, the two active sites are overlapping but not identical.

Bestatin, a general aminopeptidase inhibitor, and captopril inhibit both catalytic activities of LTA $_{4}$ hydrolase [12]. Several other potent and specific inhibitors have also been synthesized, including an $\alpha$-oxo- $\beta$-amino ester, a thioamine and a hydroxamic acid $[13,14]$.

In the present study we have used the mutants [E296Q]-, [E296D]- and [E296N]-LTA 4 hydrolase, to show that Glu-296 is a structural determinant for the tight-binding properties of bestatin, a classical prototype for an aminopeptidase inhibitor. These conclusions might also be valid for bestatin inhibition of other metallopeptidases homologous with LTA $_{4}$ hydrolase, particularly those belonging to the M1 family.

\section{EXPERIMENTAL}

\section{Materials}

LTA $_{4}$ methyl ester (Merck Frosst, Quebec, Canada) was saponified in tetrahydrofuran with $1 \mathrm{M} \mathrm{LiOH}(6 \%, v / v)$ for $48 \mathrm{~h}$ at $4{ }^{\circ} \mathrm{C}$. Bestatin and alanine-4-nitroanilide were purchased from Sigma. 4-Nitroaniline was from Kebo (Stockholm, Sweden). T7 Sequencing kit, restriction endonucleases and nucleic-acidmodifying enzymes were purchased from Amersham Pharmacia Biotech (Uppsala, Sweden). Vent DNA polymerase was from New England Biolabs (Beverly, MA, U.S.A.). Oligonucleotides were synthesized by Scandinavian Gene Synthesis AB (Köping, Sweden).

\section{Site-directed mutagenesis of $\mathrm{LTA}_{4}$ hydrolase cDNA and expression in Escherichia coli}

Mutations of recombinant mouse $\mathrm{LTA}_{4}$ hydrolase were performed by PCR mutagenesis as described [15]. Primers A and B

Abbreviations used: $\mathrm{LTA}_{4}$, leukotriene $\mathrm{A}_{4} ; \mathrm{LTB}_{4}$, leukotriene $\mathrm{B}_{4} ; \mathrm{PGB}_{1}$, prostaglandin $\mathrm{B}_{1}$

* Present address: Laboratorio Medicina Interna, Facultad de Medicina, Universidad de Navarra, 31080 Pamplona, Spain.

1 To whom correspondence should be addressed (e-mail jesper.haeggstrom@mbb.ki.se). 
were JF21 and JF27 [15]. Primer C was the mutagenetic primer in each case (site mutation underlined): JF37 (5'-GACATATCTCATAGCTGGACAGG-3') for Asp-296; JF38 (5'-AAㅡㅅㅡATCTCATAGCTGGACAGG-3') for Asn-296, both phosphorylated at the $5^{\prime}$ end. Primer D was JF13 (5'-AATCAGCAACAATCAGTTCCT-3'), a reverse primer matching nt 1856-1836 (following the cDNA numbering in [16]). Primers used for the construction of [E296Q] and [S298A]LTA 4 hydrolase were as described in [11]. Mutated proteins were expressed in $E$. coli (JM 101) transformed with the corresponding mutated plasmid, as described [15]. Sequence analysis of the entire cDNA inserts confirmed that no alterations of the protein primary structure, other than the desired mutation, had occurred.

\section{Purification of recombinant $\mathrm{LTA}_{4}$ hydrolase}

Both mutated and unmutated proteins were purified essentially as described [17]. The procedure involved precipitations, anion exchange, hydrophobic interaction and chromatofocusing chromatographies and resulted in apparently homogeneous proteins. The yield was $0.5-1 \mathrm{mg}$ of protein per litre of cell culture. After the final purification step, the buffer was changed to $50 \mathrm{mM}$ Tris/ $\mathrm{HCl}, \mathrm{pH} 8$, by repeated centrifugation on a Centricon-30 microconcentrator (Amicon, Danvers, MA, U.S.A.) and stored at $4{ }^{\circ} \mathrm{C}$. SDS/PAGE was performed on a Phast system (Pharmacia) with $10-15 \%(\mathrm{w} / \mathrm{v})$ gradient gels. Bands of protein were detected by staining with Coomassie Brilliant Blue. Protein concentrations were determined by the Bradford method [18], with BSA as standard.

\section{Determinations of enzyme activities and kinetic constants}

The kinetic constants $\left(K_{\mathrm{m}}, k_{\text {cat }}\right.$ and $\left.k_{\text {cat }} / K_{\mathrm{m}}\right)$, for the epoxide hydrolase activity (i.e. the hydrolysis of $\mathrm{LTA}_{4}$ into $\mathrm{LTB}_{4}$ ) of wild-type and [E296Q]LTA 4 hydrolase were determined by incubations of the respective enzyme $(2 \mu \mathrm{g}$ in $100 \mu \mathrm{l}$ of $50 \mathrm{mM}$ Hepes, $\mathrm{pH}$ 7.9) at room temperature for $15 \mathrm{~s}$ with the substrate $\mathrm{LTA}_{4}(5-60 \mu \mathrm{M})$, added in $1 \mu \mathrm{l}$ of tetrahydrofuran. The reaction was quenched with $200 \mu \mathrm{l}$ of methanol, and prostaglandin $\mathrm{B}_{1}$ was added as an internal standard. Product formation was analysed by reverse-phase HPLC, as described [17]. Quantifications of $\mathrm{LTB}_{4}$ were made by area integration with Baseline 810 computer software (Waters) based on a standard curve obtained from an analysis of known amounts of prostaglandin $B_{1}$ and $L_{T} B_{4}$. Kinetic data were calculated and plotted by the method of Eadie and Hofstee.

For determinations of $\mathrm{IC}_{50}$ values for bestatin, the enzyme ( $2 \mu \mathrm{g}$ in $100 \mu \mathrm{l}$ of $50 \mathrm{mM}$ Hepes, $\mathrm{pH}$ 7.9) was preincubated for $40 \mathrm{~min}$ at room temperature with various quantities of inhibitor. LTA $_{4}(20 \mu \mathrm{M})$ was added and the reaction was allowed to continue for $15 \mathrm{~s}$ before being quenched with methanol. Similar conditions were used for determinations of $\mathrm{IC}_{50}$ values for $\alpha$-oxo$\beta$-amino ester, thioamine and hydroxamic acid. For determinations of $K_{\mathrm{i}}$ values for bestatin against wild-type and [E296Q]LTA 4 hydrolase, $2 \mu \mathrm{g}$ of enzyme was incubated with $\mathrm{LTA}_{4}(8-54 \mu \mathrm{M})$ under otherwise similar conditions. The $K_{\mathrm{i}}$ values were obtained from Dixon plots [19].

The peptidase activity was determined spectrophotometrically in $50 \mathrm{mM}$ Tris $/ \mathrm{HCl}, \mathrm{pH} 7.5$, containing $100 \mathrm{mM} \mathrm{NaCl}$. The assays were performed by incubating the enzyme (1-26 $\mu \mathrm{g})$ with alanine-4-nitroanilide $(1 \mathrm{mM})$ in $250 \mu \mathrm{l}$ of buffer at room temperature, as described previously [17]. Reaction rates were calculated from the increase in $A_{405}$ over 30 min (wild-type) or 4-5 h (mutants) of incubation.

\section{RESULTS}

\section{Properties of the mutated enzymes}

In the present study we used wild-type enzyme, the previously constructed mutants [E296Q]- and [S298A]-LTA 4 hydrolase [11], and two additional mutants at position 296, namely [E296D]and [E296N]-LTA 4 hydrolase. The cDNA species were expressed in $E$. coli and the recombinant enzymes were purified to apparent homogeneity and assayed for enzyme activities. The catalytic properties of [E296Q]LTA 4 hydrolase, the most extensively used mutant in the present study, were as described in [11] and listed in Table 1. The mutants [E296D]- and [E296N]-LTA hydrolase, isolated from two or three separate expressions, were practically devoid of peptidase activity $(0.25 \%$ and $0.1 \%$ of the wild-type enzyme's) and converted $\mathrm{LTA}_{4}$ into $\mathrm{LTB}_{4}$ with specific activities of $490 \pm 120 \mathrm{nmol} / \mathrm{min}$ per $\mathrm{mg}$ (mean \pm S.D., $n=3$ ) and $310 \mathrm{nmol} / \mathrm{min}$ per $\mathrm{mg}(n=2)$, corresponding to $70 \%$ and $45 \%$ respectively of the unmutated enzyme. The properties of [E296D]and $[\mathrm{E} 296 \mathrm{~N}] \mathrm{LTA}_{4}$ hydrolase corroborate our previous conclusions on the role of Glu-296 for the peptidase activity of $\mathrm{LTA}_{4}$ hydrolase. In addition, they show that a Glu $\rightarrow$ Asp mutation, which preserves the carboxy moiety but shortens the side chain by one methylene group, also results in a loss of the peptidase activity. The peptidase activity thus depends on the presence of a carboxylate group at a correct distance from the peptide backbone of the substrate.

\section{Effects of mutations on the potency of bestatin}

Purified mutated enzymes were incubated with various concentrations of bestatin and assayed for remaining epoxide hydrolase activity. The $\mathrm{IC}_{50}$ values for the wild-type enzyme and the mutants [E296Q]-, [E296D]- and [E296N]-LTA 4 hydrolase, were calculated as being $0.14 \pm 0.09 \mu \mathrm{M}$ (mean \pm S.D., $n=5$ ), $19 \mu \mathrm{M}$ $(n=2), 5.1 \mathrm{mM}(n=1)$ and $24 \mu \mathrm{M}(n=2)$ respectively (Table 2). Thus the mutation of Glu-296 into Gln, Asp or Asn led to a decrease in inhibitor potency to $0.7 \%, 0.003 \%$ and $0.6 \%$ respectively. These effects were specific for mutations at this position because a positive control, [S298A]LTA 4 hydrolase (see Figure 1), exhibited an $\mathrm{IC}_{50}$ of $0.17 \mu \mathrm{M}$, in good agreement with that of the wild-type enzyme.

Three structurally different, tight-binding inhibitors, namely an $\alpha$-oxo- $\beta$-amino ester, a thioamine and a hydroxamic acid (Figure 2), were tested against the wild-type enzyme and [E296Q]and [E296D]-LTA 4 hydrolase. The inhibitor potencies did not differ between the mutated and unmutated enzymes, indicating that Glu-296 has an insignificant role in the binding of these drugs to the active site. Results for the hydroxamic acid are shown in Figure 3.

\section{Determination of $K_{m}, k_{\text {cat }}, K_{\mathrm{i}}^{\text {bestatin }}$ and activation energy $\left(E_{\mathrm{A}}\right)$ for wild-type and [E296Q] TA $_{4}$ hydrolase}

The catalytic properties and binding of bestatin were investigated further for wild-type and [E296Q]LTA 4 hydrolase. Thus from Eadie-Hofstee plots of kinetic data obtained from incubations of enzyme at different concentrations of substrate, the apparent $K_{\mathrm{m}}$ and $k_{\text {cat }}$ for the wild-type enzyme were calculated as being $4.9 \mu \mathrm{M}$ and $0.9 \mathrm{~s}^{-1}$ respectively (Table 1 ). In the same experiment, [E296Q]LTA 4 hydrolase exhibited a $K_{\mathrm{m}}$ of $11 \mu \mathrm{M}$ and a $k_{\text {cat }}$ of $1.4 \mathrm{~s}^{-1}$. To assess the binding between enzyme and bestatin without interference by changes in substrate affinity, the $K_{\mathrm{i}}$ for bestatin was determined from Dixon plots [19]. For wild-type and [E296Q]LTA 4 hydrolase, $K_{\mathrm{i}}$ values were calculated as 0.7 
Table 1 Kinetic constants for the formation of LTB and the binding of bestatin by the wild-type enzyme and the mutant [E296Q]LTA, hydrolase

Kinetic data were obtained from incubations of $2 \mu \mathrm{g}$ of enzyme with $\mathrm{LTA}_{4}(5-60 \mu \mathrm{M})$ for $15 \mathrm{~s}$ at room temperature. The specific activities were calculated and plotted by the method of Eadie and Hofstee. For determination of $K_{i}$, the enzyme was preincubated for 40 min with various concentrations of bestatin before the addition of $\mathrm{LTA}_{4}$. The $K_{\mathrm{i}}$ values were obtained from Dixon plots [19].

\begin{tabular}{lll}
\hline Kinetic constant & Wild-type & E296Q mutant \\
\hline$K_{\mathrm{m}}(\mu \mathrm{M})$ & 4.9 & 11 \\
$k_{\text {cat }}\left(\mathrm{s}^{-1}\right)$ & 0.9 & 1.4 \\
$10^{-5} k_{\text {cal }} / K_{\mathrm{m}}\left(\mathrm{s}^{-1} \cdot \mathrm{M}^{-1}\right)$ & 1.9 & 1.2 \\
$K_{\mathrm{i}}(\mu \mathrm{M})$ & 0.7 & 21 \\
\hline
\end{tabular}

Table 2 Effects of mutations of Glu-296 on the inhibitor potency of bestatin against the epoxide hydrolase activity of $\mathrm{LTA}_{4}$ hydrolase

Incubations were performed with $2 \mu \mathrm{g}$ of enzyme in $100 \mu \mathrm{l}$ of $50 \mathrm{mM}$ Hepes, $\mathrm{pH} 7.9$, at room temperature with the substrate $\mathrm{LTA}_{4}$, as described in the Experimental section. The enzyme was preincubated for $40 \mathrm{~min}$ with bestatin before the addition of $\mathrm{LTA}_{4}$. Abbreviation: n.d., not determined. For comparison, estimated values of $K_{\mathrm{m}}$ are also included.

\begin{tabular}{|c|c|c|c|c|c|c|}
\hline Variable & Wild-type & Mutant ... & E2960 & E296D & E296N & S298A \\
\hline $\mathrm{IC}_{50}(\mu \mathrm{M})$ & 0.14 & & 19 & 5100 & 24 & 0.17 \\
\hline$K_{m}(\mu \mathrm{M})$ & 4.9 & & 11 & $1-5^{*}$ & 5 & n.d. \\
\hline
\end{tabular}

and $21 \mu \mathrm{M}$ respectively (Table 1). For the mutants [E296D]- and [E296N]-LTA 4 hydrolase, no detailed graphical determinations of apparent kinetic constants were made. However, from incubations of these mutants with $\mathrm{LTA}_{4}$ at 5,15 and $60 \mu \mathrm{M}, K_{\mathrm{m}}$ values for [E296D]- and [E296N]-LTA 4 hydrolase were estimated at $1 \mu \mathrm{M}<K_{\mathrm{m}}<5 \mu \mathrm{M}$ and $5 \mu \mathrm{M}$ respectively (results not shown). Apparently, none of the mutations caused any significant change in the $K_{\mathrm{m}}$ for $\mathrm{LTA}_{4}$.

The specific epoxide hydrolase activity of [E296Q]LTA hydrolase was more sensitive to temperature changes than that of the unmutated enzyme. From kinetic data obtained at different temperatures $\left(0,7,15\right.$ and $\left.30^{\circ} \mathrm{C}\right)$, the relative increase in specific activity per $10^{\circ} \mathrm{C}\left(Q_{10}\right)$ for wild-type and [E296Q]LTA hydrolase were calculated as $17 \%$ and $49 \%$ respectively (five experiments). The change in specific activity was not always linear over the whole temperature range, which might reflect sudden, temperature-dependent, transitions between different protein conformations. The $E_{\mathrm{A}}$ values for wild-type and [E296Q]LTA 4 hydrolase were calculated from Arrhenius plots $(\log V$ against $1 / T)$ as $3.3 \pm 0.4 \mathrm{~kJ} / \mathrm{mol}(\operatorname{mean} \pm$ S.D., $n=3)$ and $17.5 \pm 5 \mathrm{~kJ} / \mathrm{mol}(n=$ 4) respectively.

\section{DISCUSSION}

Certain metallopeptidases share a conserved Glu in their $\mathrm{Zn}^{2+}$ binding motifs (Figure 1). This signature is also present in LTA hydrolase and we have previously shown that the corresponding Glu-296 is a catalytic residue, which presumably activates the water molecule during peptidolysis [11]. In the present study we took advantage of the epoxide hydrolase activity, i.e. the conversion of $\mathrm{LTA}_{4}$ into $\mathrm{LTB}_{4}$, of the mutants [E296Q]-, [E296D]- and [E296N]-LTA 4 hydrolase to explore the role of Glu296 for the tight-binding properties of bestatin and three other specific $\mathrm{LTA}_{4}$ hydrolase inhibitors.

Bestatin is a classical inhibitor of aminopeptidases, efficient against, for example, the dizinc peptidase leucyl aminopeptidase as well as the monozinc peptidases aminopeptidase B and LTA $_{4}$ hydrolase [12,20,21]. Furthermore, it has been suggested that a $\mathrm{Zn}^{2+}$ ion and an acidic residue are involved in the binding of the drug to the active site [20,22]. Because bestatin is a prototype for an aminopeptidase inhibitor and many newly synthesized com-<smiles>CC(C)C[C@H](NC(=O)[C@@H](O)[C@H](N)Cc1ccccc1)C(=O)O</smiles><smiles>N[C@@H](Cc1ccc(OCc2ccccc2)cc1)C(=O)C(=O)OCc1ccccc1</smiles><smiles>N[C@@H](CS)Cc1ccc(OCc2ccccc2)cc1</smiles><smiles>N[C@@H](Cc1ccc(OCc2ccccc2)cc1)CN(O)C(=O)CCCCC(=O)O</smiles>

\section{Bestatin}

$\alpha$-Keto- $\beta$-amino ester

Thioamine

Amino hydroxamic acid

Figure 2 Structures of four tight-binding inhibitors of LTA ${ }_{4}$ hydrolase 

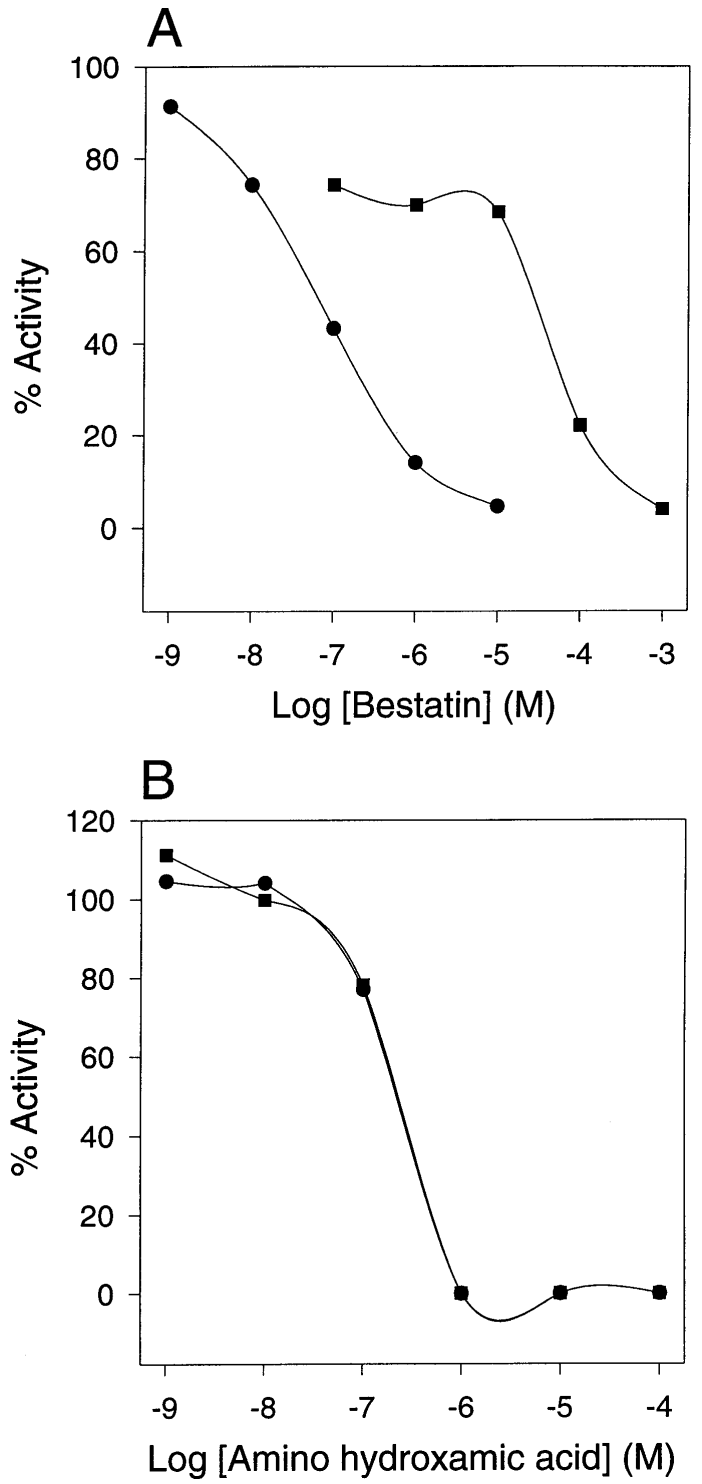

Figure 3 Inhibition of the epoxide hydrolase activity of wild-type $(O)$ and [E296Q] $\mathrm{LTA}_{4}$ hydrolase $(\square)$ by bestatin (A) and amino hydroxamic acid (B)

Enzyme $(2 \mu \mathrm{g})$ in $100 \mu \mathrm{l}$ of $50 \mathrm{mM}$ Hepes, $\mathrm{pH} 7.9$, was preincubated with various quantities of inhibitor for 40-60 min at room temperature. LTA $(20 \mu \mathrm{M})$ was added and the reaction was stopped after $15 \mathrm{~s}$ by being quenched with $2 \mathrm{vol}$. of methanol. The internal standard prostaglandin $B_{1}$ was added and the samples were subjected to solid-phase extraction and reverse-phase HPLC for the analysis of $\mathrm{LTB}_{4}$ formation.

pounds have been developed with bestatin as a template [23-25], we investigated the potential involvement of Glu-296 in the binding of bestatin and three other more specific and tightbinding inhibitors of $\mathrm{LTA}_{4}$ hydrolase. Interestingly, for all mutants of Glu-296, i.e. [E296Q]-, [E296D]- and [E296N]-LTA hydrolase, we found that the inhibitor potency of bestatin decreased markedly to $0.7-0.003 \%$ of the potency towards the wild-type enzyme. This effect is specific for Glu-296 because a control mutant, [S298A]LTA 4 hydrolase, exhibited an $\mathrm{IC}_{50}$ $(0.17 \mu \mathrm{M})$ similar to that of wild-type enzyme $(0.14 \mu \mathrm{M})$. A more detailed kinetic examination of wild-type and [E296Q]LTA hydrolase revealed similar $K_{\mathrm{m}}$ values for $\mathrm{LTA}_{4}$ and the values of $K_{\mathrm{i}}$ for bestatin were in good agreement with the $\mathrm{IC}_{50}$ values

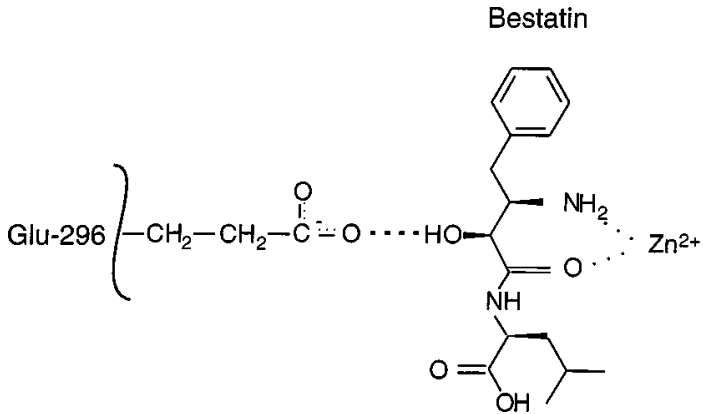

Figure 4 Model for the binding of bestatin to the active site of LTA $_{4}$ hydrolase

A proposed mechanism for inhibition with bestatin is shown, in which the free amine and the carbonyl oxygen are co-ordinated to the $\mathrm{Zn}^{2+}$ ion and the intervening hydroxy group is coordinated to a carboxylate group of the enzyme.

(Tables 1 and 2). Estimation of the $K_{\mathrm{m}}$ for [E296D]- and [E296N]-LTA 4 hydrolase also showed that a change in substrate affinity could hardly account for the large decrease in inhibitor potency. However, these estimations were performed in a rather crude fashion and therefore we cannot rule out the possibility that minor alterations in $K_{\mathrm{m}}$ contribute to the effect. In any event, Glu-296 seems to be an important structural determinant for the binding of bestatin, probably owing to its charged carboxylate. A putative model for the inhibitor binding is depicted in Figure 4. Because the equivalent of Glu-296 is conserved within the $\mathrm{Zn}^{2+}$-binding motifs of certain metalloproteases, our conclusions might prove applicable to the inhibition of other members of this enzyme class, particularly those belonging to the M1 family of zinc peptidases, by bestatin [9].

Considering the differences between mutants with regard to loss of inhibitor potency, it seems likely that structural features of the active site, other than Glu-296, also influence the binding of inhibitor. Thus each of the mutations might induce minor conformational changes at the active site that can improve or weaken the binding. Experimental evidence in support of such structural changes was the increased activation energy of [E296Q]LTA 4 hydrolase. Nevertheless, for all mutants tested, bestatin was a very poor inhibitor.

The loss of inhibitor potency was specific for bestatin. Thus, of four potent tight-binding inhibitors, bestatin was the only one that became essentially inactive against the mutants in position 296 (compare Figures 2 and 3). Glu-296 has been suggested to participate in the binding of all these inhibitors [14,23-25] but the $\mathrm{IC}_{50}$ values for each of the $\alpha$-oxo- $\beta$-amino ester, the thioamine and the hydroxamic acid were almost identical for the wildtype, [E296Q]- and [E296D]-LTA hydrolases respectively. Apparently, Glu-296 does not have a major role in the binding of these inhibitors to the active site of $\mathrm{LTA}_{4}$ hydrolase. A comparison of the four inhibitor structures (Figure 2) rather suggests that the bicyclic hydrophobic portions of the the $\alpha$-oxo- $\beta$-amino ester, the thioamine and the hydroxamic acid, which mimic the fatty acid backbone of $\mathrm{LTA}_{4}$, are more important for the tight binding properties of these compounds.

We thank Ms. Eva Ohlson for excellent technical assistance, Dr. A. W. FordHutchinson (Merck-Frosst, Canada) for the generous gift of $\mathrm{LTA}_{4}$, and Dr. Chi-Huey Wong (Scripps Research Institute, La Jolla, CA, U.S.A.) for samples of enzyme inhibitors. This project was financially supported by the Swedish Medical Research 
Council (03X-10350), the Swedish Medical Society, Konung Gustav V: s 80-årsfond, and the Knut \& Alice Wallenberg Foundation.

\section{REFERENCES}

1 Samuelsson, B. (1983) Science 220, 568-575

2 Mueller, M. J., Wetterholm, A., Blomster, M., Jörnvall, H., Samuelsson, B. and Haeggström, J. Z. (1995) Proc. Natl. Acad. Sci. U.S.A. 92, 8383-8387

3 Mueller, M. J., Blomster, M., Oppermann, U. C., Jörnvall, H., Samuelsson, B. and Haeggström, J. Z. (1996) Proc. Natl. Acad. Sci. U.S.A. 93, 5931-5935

4 Malfroy, B., Kado-Fong, H., Gros, C., Giros, B., Schwartz, J.-C. and Hellmiss, R. (1989) Biochem. Biophys. Res. Commun. 161, 236-241

5 Haeggström, J. Z., Wetterholm, A., Vallee, B. L. and Samuelsson, B. (1990) Biochem. Biophys. Res. Commun. 173, 431-437

6 Minami, M., Ohishi, N., Mutoh, H., Izumi, T., Bito, H., Wada, H., Seyama, Y., Toh, H. and Shimizu, T. (1990) Biochem. Biophys. Res. Commun. 173, 620-626

7 Haeggström, J. Z., Wetterholm, A., Shapiro, R., Vallee, B. L. and Samuelsson, B. (1990) Biochem. Biophys. Res. Commun. 172, 965-970

8 Orning, L., Gierse, J. K. and Fitzpatrick, F. A. (1994) J. Biol. Chem. 269 11269-11273

9 Barret, A. J., Rawlings, N. D. and Woessner, J. F. (1998) Handbook of Proteolytic Enzymes, pp. 994-996, Academic Press, London

10 Vallee, B. L. and Auld, D. S. (1990) Biochemistry 29, 5647-5659

11 Wetterholm, A., Medina, J. F., Rådmark, 0., Shapiro, R., Haeggström, J. Z., Vallee, B. L. and Samuelsson, B. (1992) Proc. Natl. Acad. Sci. U.S.A. 89, 9141-9145
12 Orning, L., Krivi, G. and Fitzpatrick, F. A. (1991) J. Biol. Chem. 266, 1375-1378

13 Wetterholm, A., Haeggström, J. Z., Samuelsson, B., Yuan, W., Munoz, B. and Wong, C. H. (1995) J. Pharm. Exp. Ther. 275, 31-37

14 Hogg, J. H., Ollmann, I. R., Haeggström, J. Z., Wetterholm, A., Samuelsson, B. and Wong, C. H. (1995) Bioorg. Med. Chem. 3, 1405-1415

15 Medina, J. F., Wetterholm, A., Rådmark, 0., Shapiro, R., Haeggström, J. Z., Vallee, B. L. and Samuelsson, B. (1991) Proc. Natl. Acad. Sci. U.S.A. 88, 7620-7624

16 Medina, J. F., Rådmark, 0., Funk, C. D. and Haeggström, J. Z. (1991) Biochem. Biophys. Res. Commun. 176, 1516-1524

17 Wetterholm, A., Medina, J. F., Rådmark, 0., Shapiro, R., Haeggström, J. Z., Vallee, B. L. and Samuelsson, B. (1991) Biochim. Biophys. Acta 1080, 96-102

18 Bradford, M. M. (1976) Anal. Biochem. 72, 248-254

19 Dixon, M. (1972) Biochem. J. 129, 197-202

20 Burley, S. K., David, P. R. and Lipscomb, W. N. (1991) Proc. Natl. Acad. Sci. U.S.A 88, 6916-6920

21 Cadel, S., Pierotti, A. R., Foulon, T., Créminon, C., Barré, N., Segrétain, D. and Cohen, P. (1995) Mol. Cell. Endocrinol. 110, 149-160

22 Gordon, E. M., Godfrey, J. D., Delaney, N. G., Asaad, M. M., Von Langen, D. and Cushman, D. W. (1988) J. Med. Chem. 31, 2199-2211

23 Yuan, W., Zhong, Z., Wong, C.-H., Haeggström, J. Z., Wetterholm, A. and Samuelsson, B. (1991) Bioorg. Med. Chem. Lett. 1, 551-556

24 Yuan, W., Wong, C.-H., Haeggström, J. Z., Wetterholm, A. and Samuelsson, B. (1992) J. Am. Chem. Soc. 114, 6552-6553

25 Yuan, W., Munoz, B., Wong, C. H., Haeggström, J. Z., Wetterholm, A. and Samuelsson, B. (1993) J. Med. Chem. 36, 211-220

Received 8 October 1999; accepted 12 November 1999 